\title{
Regional and chronological differences in prevalences of olfactory and gustatory dysfunction in coronavirus disease (COVID-19): a systemic review and meta- analysis
}

\section{Jeong-Whun Kim}

Seoul National University College of Medicine

\section{Seung Cheol Han}

Seoul National University College of Medicine

\section{Hyung Dong Jo}

Seoul National University College of Medicine

\section{Sung-Woo Cho}

Seoul National University College of Medicine Jin Youp Kim ( $\sim$ kjyoup0622@gmail.com )

Seoul National University College of Medicine, Seoul National University Bundang Hospital https://orcid.org/0000-0003-2687-6919

\section{Research Article}

Keywords: Coronavirus; Smell; Taste; Meta-Analysis; Geographic location

Posted Date: August 14th, 2020

DOl: https://doi.org/10.21203/rs.3.rs-58460/v1

License: @ (i) This work is licensed under a Creative Commons Attribution 4.0 International License. Read Full License 


\section{Abstract}

Olfactory and gustatory dysfunction are frequently reported in patients with coronavirus disease (COVID-19). However, the reported prevalence of olfactory and/or gustatory dysfunction varies widely, and the reason for the inter-study differences is unclear. Hence, in this meta-analysis, we performed subgroup analyses to investigate the factors that contribute to the inter-study variability in the prevalence of olfactory and gustatory dysfunction. Out of 943 citations, we included 55 eligible studies with 13,527 patients with COVID-19 for a systematic review. The overall pooled prevalences of olfactory and gustatory dysfunction were $51.4 \%$ and $47.5 \%$, respectively, in the random-effect model. In subgroup analyses, the prevalences of olfactory and gustatory dysfunction were significantly different among four geographical regions (both $\mathrm{P}<0.001$, respectively). Although the prevalences of olfactory and gustatory dysfunction did not significantly differ according to the time of enrollment, the subgroup analyses including only studies from the same geographical region (Europe) revealed a significant difference in olfactory dysfunction according to the time of enrollment. The regional and chronological differences in the prevalences of olfactory and gustatory dysfunctions partly explain the wide inter-study variability.

\section{Introduction}

Coronavirus disease (COVID-19), caused by the severe acute respiratory syndrome coronavirus 2 (SARS-CoV2), has spread rapidly worldwide since it was first identified in Wuhan, China in 2019. Although most COVID-19 patients have mild clinical manifestations, about $5 \%$ progress to critical status with respiratory failure and/or multi-organ failure. ${ }^{1}$ A previous study suggested that the sinonasal tract may play a significant role in the infection, transmission, and pathogenesis of the SARS-CoV- $2 .{ }^{2}$ In addition, nasal swabs from symptomatic patients with COVID-19 had higher viral loads than throat swabs. ${ }^{3}$ As the olfactory sensory neurons directly contact the environment in the nasal cavity, these neurons may be vulnerable to the exposure of the high viral load of SARS-CoV-2 in the nasal cavity.

Olfactory and gustatory dysfunction are frequently reported in patients with COVID-19 and are noted as significant symptoms in COVID-19. The prevalence of olfactory and gustatory dysfunction in previous studies varies from $5.1 \%$ to $98.3 \%$ and $5.6 \%$ to $92.7 \%$, respectively ${ }^{4}$; however, the reason for the inter-study differences is unclear. In addition, a recent meta-analysis showed that the prevalences of olfactory and gustatory dysfunction were $52.7 \%$ and $54.9 \%$ in COVID-19 patients, respectively; however, a significant heterogeneity $\left(I^{2}=\right.$ $98.9 \%$ for both, prevalences of olfactory and gustatory dysfunction) was detected. ${ }^{4}$ In contrast to Europe where the prevalence of olfactory dysfunction was found to be more than $50 \%$ in many studies, we noted that most studies conducted in Asia showed the prevalence of olfactory dysfunction to be less than $50 \%{ }^{5-9}$ Therefore, we hypothesized that the prevalences of olfactory and gustatory dysfunction are geographically and chronologically different, and this may explain the heterogeneity of the prevalences of olfactory and gustatory dysfunction. In this meta-analysis, we performed subgroup analysis to investigate factors, such as geographical region and enrollment time, that contributed to the inter-study variability of the prevalences of olfactory and gustatory dysfunction.

\section{Results}


Initially, of the 943 citations identified through the search strategy, we included 55 eligible studies for systematic review (Fig. 1). ${ }^{5-58}$

\section{Study characteristics}

The characteristics of the included studies are summarized in Table 1. The total sample size of the 55 included studies was 13,527 patients with individual sample sizes ranging from 16-3,191 patients. All included studies reported the prevalence of olfactory dysfunction in COVID-19, while 46 studies reported the prevalence of gustatory dysfunction. All included studies were conducted in 2020, and they were performed across 19 countries. There were four regions with at least one study: East Asia $(n=7)$, Europe $(n=35)$, North America ( $n$ $=8)$, Middle East $(n=5)$. The region with the most individual studies was Europe $(n=35)$, including 16 studies conducted in Italy. Two multicenter studies conducted in Europe were included. Out of 55 included studies, 29 clarified when patients were enrolled. Considering the characteristics of the population of individual studies, there were 29 studies of the general population, including both hospitalized and non-hospitalized patients, 15 studies of only hospitalized patients, eight studies of only non-hospitalized patients, and three studies of healthcare workers. Ten studies used history taking of olfactory and/or gustatory evaluation, 31 used selfreported surveys, six used a validated survey, and eight used validated instruments. Patients were diagnosed as COVID-19 by real-time polymerase chain reaction (RT-PCR) in most studies, except four 6,20,46,48 that did not report the testing tool.

Table 1. Summary of the included studies. 


\begin{tabular}{|c|c|c|c|c|c|c|c|c|c|}
\hline Authors & Region & Country & Study design & $\begin{array}{l}\text { The tim } \\
\text { of } \\
\text { enrollm }\end{array}$ & & Population & Age & $\begin{array}{l}\text { Evaluating } \\
\text { method }\end{array}$ & $\begin{array}{c}\text { Sample } \\
\text { size }\end{array}$ \\
\hline Liang et $\mathrm{al}^{7}$ & $\begin{array}{l}\text { East } \\
\text { Asia }\end{array}$ & China & $\mathrm{CS}$ & $\begin{array}{l}03-16- \\
2020 \\
04-12- \\
2020\end{array}$ & to & $\begin{array}{l}\text { Hospitalized } \\
\text { population }\end{array}$ & $25.5^{\ddagger}$ & $\begin{array}{l}\text { Self- } \\
\text { reported } \\
\text { survey }\end{array}$ & 86 \\
\hline Mao et $\mathrm{al}^{8}$ & $\begin{array}{l}\text { East } \\
\text { Asia }\end{array}$ & China & $\mathrm{CS}$ & $\begin{array}{l}01-16- \\
2020 \\
02-19- \\
2020\end{array}$ & to & $\begin{array}{l}\text { Hospitalized } \\
\text { population }\end{array}$ & $52.7^{\dagger}$ & $\begin{array}{l}\text { History } \\
\text { taking }\end{array}$ & 214 \\
\hline $\begin{array}{l}\text { Chung et } \\
\mathrm{al}^{53}\end{array}$ & $\begin{array}{l}\text { East } \\
\text { Asia }\end{array}$ & $\begin{array}{l}\text { China } \\
\text { (Hongkong) }\end{array}$ & $\begin{array}{l}\text { Retrospective } \\
\text { case-control } \\
\text { study }\end{array}$ & $\begin{array}{l}04-06- \\
2020 \\
04-09- \\
2020\end{array}$ & to & $\begin{array}{l}\text { Hospitalized } \\
\text { population }\end{array}$ & Unknown & $\begin{array}{l}\text { Validated } \\
\text { survey }\end{array}$ & 18 \\
\hline${\mathrm{Kim} \mathrm{et} \mathrm{al}^{5}}^{5}$ & $\begin{array}{l}\text { East } \\
\text { Asia }\end{array}$ & Korea & $\mathrm{CS}$ & $\begin{array}{l}03-12- \\
2020 \\
03-16- \\
2020\end{array}$ & to & $\begin{array}{l}\text { Non- } \\
\text { hospitalized } \\
\text { population }\end{array}$ & $26^{\ddagger}$ & $\begin{array}{l}\text { Self- } \\
\text { reported } \\
\text { survey }\end{array}$ & 213 \\
\hline Lee et $\mathrm{al}^{6}$ & $\begin{array}{l}\text { East } \\
\text { Asia }\end{array}$ & Korea & $\mathrm{CS}$ & $\begin{array}{l}03-08- \\
2020 \\
03-31- \\
2020\end{array}$ & to & $\begin{array}{l}\text { General } \\
\text { population }\end{array}$ & $44^{\dagger}$ & $\begin{array}{l}\text { History } \\
\text { taking }\end{array}$ & 3191 \\
\hline Noh et $\mathrm{al}^{9}$ & $\begin{array}{l}\text { East } \\
\text { Asia }\end{array}$ & Korea & $\mathrm{CS}$ & NA & & $\begin{array}{l}\text { Non- } \\
\text { hospitalized } \\
\text { population }\end{array}$ & $38^{\dagger}$ & $\begin{array}{l}\text { History } \\
\text { taking }\end{array}$ & 199 \\
\hline Chua et al ${ }^{17}$ & $\begin{array}{l}\text { East } \\
\text { Asia }\end{array}$ & Singapore & CS & $\begin{array}{l}03-23- \\
2020 \\
04-04- \\
2020\end{array}$ & to & $\begin{array}{l}\text { General } \\
\text { population }\end{array}$ & Unknown & $\begin{array}{l}\text { Self- } \\
\text { reported } \\
\text { survey }\end{array}$ & 31 \\
\hline $\begin{array}{ll}\text { Lechien } & \text { et } \\
\mathrm{al}^{28} & \end{array}$ & Europe & $\begin{array}{l}\text { Four } \\
\text { European } \\
\text { countries }\end{array}$ & $\mathrm{CS}$ & NA & & $\begin{array}{l}\text { General } \\
\text { population }\end{array}$ & $36.9^{\dagger}$ & $\begin{array}{l}\text { Validated } \\
\text { survey }\end{array}$ & 417 \\
\hline $\begin{array}{ll}\text { Lechien } & \text { et } \\
\mathrm{al}^{29} & \end{array}$ & Europe & $\begin{array}{l}\text { Five } \\
\text { European } \\
\text { countries }\end{array}$ & $\mathrm{CS}$ & NA & & $\begin{array}{l}\text { General } \\
\text { population }\end{array}$ & $39.2^{\dagger}$ & $\begin{array}{l}\text { Self- } \\
\text { reported } \\
\text { survey }\end{array}$ & 1420 \\
\hline $\begin{array}{ll}\text { Iravani, } & \text { B. } \\
\text { et } \mathrm{al}^{23} & \end{array}$ & Europe & France & $\begin{array}{l}\text { Retrospective } \\
\text { case series }\end{array}$ & $\begin{array}{l}03-01- \\
2020 \\
03-17- \\
2020\end{array}$ & to & $\begin{array}{l}\text { General } \\
\text { population }\end{array}$ & $47^{\dagger}$ & $\begin{array}{l}\text { Self- } \\
\text { reported } \\
\text { survey }\end{array}$ & 114 \\
\hline $\begin{array}{ll}\text { Lechien } & \text { et } \\
\mathrm{al}^{27} & \end{array}$ & Europe & France & $\mathrm{CS}$ & NA & & $\begin{array}{l}\text { General } \\
\text { population }\end{array}$ & $41.7^{\dagger}$ & $\begin{array}{l}\text { Validated } \\
\text { instrument }\end{array}$ & 86 \\
\hline $\begin{array}{l}\text { Renaud et } \\
\mathrm{al}^{40}\end{array}$ & Europe & France & $\mathrm{CS}$ & NA & & $\begin{array}{l}\text { General } \\
\text { population }\end{array}$ & $35^{\ddagger}$ & $\begin{array}{l}\text { Self- } \\
\text { reported } \\
\text { survey }\end{array}$ & 97 \\
\hline Zayet et al ${ }^{51}$ & Europe & France & $\begin{array}{l}\text { Retrospective } \\
\text { case-control } \\
\text { study }\end{array}$ & NA & & $\begin{array}{l}\text { Non- } \\
\text { hospitalized } \\
\text { population }\end{array}$ & $40^{\dagger}$ & $\begin{array}{l}\text { Self- } \\
\text { reported } \\
\text { survey }\end{array}$ & 95 \\
\hline Zayet et $\mathrm{al}^{52}$ & Europe & France & $\begin{array}{l}\text { Retrospective } \\
\text { case-control } \\
\text { study }\end{array}$ & $\begin{array}{l}02-26- \\
2020 \\
03-14- \\
2020\end{array}$ & to & $\begin{array}{l}\text { General } \\
\text { population }\end{array}$ & $57^{\dagger}$ & $\begin{array}{l}\text { Self- } \\
\text { reported } \\
\text { survey }\end{array}$ & 70 \\
\hline $\begin{array}{l}\text { Brandstetter } \\
\text { et } \mathrm{al}^{15}\end{array}$ & Europe & Germany & CS & NA & & $\begin{array}{l}\text { Healthcare } \\
\text { workers }\end{array}$ & Unknown & $\begin{array}{l}\text { Self- } \\
\text { reported } \\
\text { survey }\end{array}$ & 31 \\
\hline $\begin{array}{l}\text { Hintschich } \\
\text { et } \mathrm{al}^{54}\end{array}$ & Europe & Germany & $\mathrm{CS}$ & NA & & $\begin{array}{l}\text { General } \\
\text { population }\end{array}$ & Unknown & $\begin{array}{l}\text { Validated } \\
\text { instrument }\end{array}$ & 41 \\
\hline Luers et $\mathrm{al}^{33}$ & Europe & Germany & $\mathrm{CS}$ & $\begin{array}{l}03-22- \\
2020 \\
03-28- \\
2020\end{array}$ & to & $\begin{array}{l}\text { Non- } \\
\text { hospitalized } \\
\text { population }\end{array}$ & $38^{\dagger}$ & $\begin{array}{l}\text { Self- } \\
\text { reported } \\
\text { survey }\end{array}$ & 72 \\
\hline
\end{tabular}


Tsivgoulis et Europe Greece CS

CS $\quad$ 03-19- Hospitalized $\quad 55^{\dagger} \quad$ Validated 22

$\mathrm{al}^{45}$

2020 to population instrument

(1)

04-08-

2020

\begin{tabular}{|c|c|c|c|c|c|c|c|c|c|}
\hline $\begin{array}{l}\text { De Maria et } \\
\mathrm{al}^{19}\end{array}$ & Europe & Italy & $\overline{\mathrm{CS}}$ & $\overline{\mathrm{NA}}$ & & $\begin{array}{l}\text { Non- } \\
\text { hospitalized } \\
\text { population }\end{array}$ & Unknown & $\begin{array}{l}\text { Self- } \\
\text { reported } \\
\text { survey }\end{array}$ & 92 \\
\hline $\begin{array}{ll}\text { Dell'Era et } \\
\mathrm{al}^{20}\end{array}$ & Europe & Italy & $\mathrm{CS}$ & $\begin{array}{l}03-10- \\
2020 \\
03-30- \\
2020\end{array}$ & to & $\begin{array}{l}\text { General } \\
\text { population }\end{array}$ & $50^{\ddagger}$ & $\begin{array}{l}\text { Validated } \\
\text { survey }\end{array}$ & 355 \\
\hline Freni et al ${ }^{21}$ & Europe & Italy & $\mathrm{CS}$ & NA & & $\begin{array}{l}\text { General } \\
\text { population }\end{array}$ & $37.7^{\dagger}$ & $\begin{array}{l}\text { Validated } \\
\text { survey }\end{array}$ & 50 \\
\hline $\begin{array}{ll}\text { Gelardi } & \text { et } \\
\mathrm{al}^{22} & \end{array}$ & Europe & Italy & $\begin{array}{l}\text { Retrospective } \\
\text { case series }\end{array}$ & NA & & $\begin{array}{l}\text { General } \\
\text { population }\end{array}$ & $49.7^{\dagger}$ & $\begin{array}{l}\text { History } \\
\text { taking }\end{array}$ & 72 \\
\hline $\begin{array}{ll}\text { Karadaş et } & \text { et } \\
\mathrm{al}^{25} & \end{array}$ & Europe & Italy & $\mathrm{CS}$ & NA & & $\begin{array}{l}\text { Hospitalized } \\
\text { population }\end{array}$ & $46.5^{\dagger}$ & $\begin{array}{l}\text { History } \\
\text { taking }\end{array}$ & 239 \\
\hline Lagi et $\mathrm{al}^{26}$ & Europe & Italy & $\mathrm{CS}$ & $\begin{array}{l}02-25- \\
2020 \\
03-26- \\
2020\end{array}$ & to & $\begin{array}{l}\text { Hospitalized } \\
\text { population }\end{array}$ & $62^{\ddagger}$ & $\begin{array}{l}\text { History } \\
\text { taking }\end{array}$ & 68 \\
\hline $\begin{array}{ll}\text { Liguori } & \text { et } \\
\mathrm{al}^{32} & \end{array}$ & Europe & Italy & $\overline{\mathrm{CS}}$ & NA & & $\begin{array}{l}\text { Hospitalized } \\
\text { population }\end{array}$ & $55^{\dagger}$ & $\begin{array}{l}\text { History } \\
\text { taking }\end{array}$ & 103 \\
\hline Meini et $\mathrm{al}^{34}$ & Europe & Italy & $\mathrm{CS}$ & NA & & $\begin{array}{l}\text { Hospitalized } \\
\text { population }\end{array}$ & $65^{\dagger}$ & $\begin{array}{l}\text { Self- } \\
\text { reported } \\
\text { survey }\end{array}$ & 100 \\
\hline $\begin{array}{l}\text { Mercante et } \\
\mathrm{al}^{35}\end{array}$ & Europe & Italy & $\mathrm{CS}$ & $\begin{array}{l}03-05- \\
2020 \\
03-23- \\
2020\end{array}$ & to & $\begin{array}{l}\text { General } \\
\text { population }\end{array}$ & $52.6^{\dagger}$ & $\begin{array}{l}\text { Self- } \\
\text { reported } \\
\text { survey }\end{array}$ & 204 \\
\hline $\begin{array}{ll}\text { Paderno } & \text { et } \\
\mathrm{al}^{56} & \end{array}$ & Europe & Italy & $\mathrm{CS}$ & NA & & $\begin{array}{l}\text { General } \\
\text { population }\end{array}$ & $55^{\dagger}$ & $\begin{array}{l}\text { Self- } \\
\text { reported } \\
\text { survey }\end{array}$ & 508 \\
\hline $\begin{array}{ll}\text { Paderno } & \text { et } \\
\mathrm{al}^{36} & \end{array}$ & Europe & Italy & $\mathrm{CS}$ & $\begin{array}{l}03-27- \\
2020 \\
04-01- \\
2020\end{array}$ & to & $\begin{array}{l}\text { Non- } \\
\text { hospitalized } \\
\text { population }\end{array}$ & $45^{\dagger}$ & $\begin{array}{l}\text { Self- } \\
\text { reported } \\
\text { survey }\end{array}$ & 151 \\
\hline $\begin{array}{l}\text { Petrocelli et } \\
\mathrm{al}^{38}\end{array}$ & Europe & Italy & $\mathrm{CS}$ & $\begin{array}{l}03-16- \\
2020 \\
05-02- \\
2020\end{array}$ & to & $\begin{array}{l}\text { General } \\
\text { population }\end{array}$ & $43.6^{\dagger}$ & $\begin{array}{l}\text { Validated } \\
\text { instrument }\end{array}$ & 300 \\
\hline $\begin{array}{l}\text { Vacchiano et } \\
\mathrm{al}^{46}\end{array}$ & Europe & Italy & $\mathrm{CS}$ & NA & & $\begin{array}{l}\text { Hospitalized } \\
\text { population }\end{array}$ & $59^{\ddagger}$ & $\begin{array}{l}\text { Self- } \\
\text { reported } \\
\text { survey }\end{array}$ & 108 \\
\hline Vaira et $\mathrm{al}^{47}$ & Europe & Italy & $\mathrm{CS}$ & $\begin{array}{l}03-31- \\
2020 \\
04-06- \\
2020\end{array}$ & to & $\begin{array}{l}\text { General } \\
\text { population }\end{array}$ & $49.2^{\dagger}$ & $\begin{array}{l}\text { Validated } \\
\text { instrument }\end{array}$ & 72 \\
\hline Vaira et $\mathrm{al}^{48}$ & Europe & Italy & $\begin{array}{l}\text { Retrospective } \\
\text { case series }\end{array}$ & NA & & $\begin{array}{l}\text { General } \\
\text { population }\end{array}$ & $48.5^{\dagger}$ & $\begin{array}{l}\text { Validated } \\
\text { instrument }\end{array}$ & 256 \\
\hline Vaira et $\mathrm{al}^{49}$ & Europe & Italy & CS & NA & & $\begin{array}{l}\text { Healthcare } \\
\text { workers }\end{array}$ & $47.2^{\dagger}$ & $\begin{array}{l}\text { Validated } \\
\text { instrument }\end{array}$ & 33 \\
\hline $\begin{array}{l}\text { Tostmann et } \\
\mathrm{al}^{44}\end{array}$ & Europe & Netherland & $\begin{array}{l}\text { Retrospective } \\
\text { case-control } \\
\text { study }\end{array}$ & $\begin{array}{l}03-10- \\
2020 \\
03-23- \\
2020\end{array}$ & to & $\begin{array}{l}\text { Healthcare } \\
\text { workers }\end{array}$ & Unknown & $\begin{array}{l}\text { Self- } \\
\text { reported } \\
\text { survey }\end{array}$ & 79 \\
\hline $\begin{array}{l}\text { Sierpiński et } \\
\mathrm{al}^{43}\end{array}$ & Europe & Poland & $\mathrm{CS}$ & NA & & $\begin{array}{l}\text { Non- } \\
\text { hospitalized } \\
\text { population }\end{array}$ & $50^{\ddagger}$ & $\begin{array}{l}\text { Self- } \\
\text { reported } \\
\text { survey }\end{array}$ & 1942 \\
\hline $\begin{array}{l}\text { Abalo-Lojo } \\
\text { et } \mathrm{al}^{10}\end{array}$ & Europe & spain & $\mathrm{CS}$ & NA & & $\begin{array}{l}\text { General } \\
\text { population }\end{array}$ & Unknown & $\begin{array}{l}\text { Self- } \\
\text { reported }\end{array}$ & 131 \\
\hline
\end{tabular}




\begin{tabular}{|c|c|c|c|c|c|c|c|c|c|}
\hline & & & & & & & & survey & \\
\hline $\begin{array}{l}\text { Beltrán- } \\
\text { Corbellini et } \\
\mathrm{al}^{13}\end{array}$ & Europe & Spain & $\mathrm{CS}$ & $\begin{array}{l}03-23- \\
2020 \\
03-25- \\
2020\end{array}$ & to & $\begin{array}{l}\text { Hospitalized } \\
\text { population }\end{array}$ & $61.6^{\dagger}$ & $\begin{array}{l}\text { Self- } \\
\text { reported } \\
\text { survey }\end{array}$ & 79 \\
\hline $\begin{array}{l}\text { Izquierdo- } \\
\text { Dominguez } \\
\text { et } \mathrm{al}^{24}\end{array}$ & Europe & Spain & $\mathrm{CS}$ & $\begin{array}{l}03-21- \\
2020 \\
04-21- \\
2020\end{array}$ & to & $\begin{array}{l}\text { General } \\
\text { population }\end{array}$ & $56.8^{\dagger}$ & $\begin{array}{l}\text { Validated } \\
\text { survey }\end{array}$ & 846 \\
\hline Speth et al ${ }^{2}$ & Europe & Switzerland & $\mathrm{CS}$ & $\begin{array}{l}03-03- \\
2020 \\
04-17- \\
2020\end{array}$ & to & $\begin{array}{l}\text { General } \\
\text { population }\end{array}$ & $46.8^{\dagger}$ & $\begin{array}{l}\text { Self- } \\
\text { reported } \\
\text { survey }\end{array}$ & 103 \\
\hline Altin et $\mathrm{al}^{12}$ & Europe & Turkey & CS & $\begin{array}{l}03-25- \\
2020 \\
04-20- \\
2020\end{array}$ & to & $\begin{array}{l}\text { Hospitalized } \\
\text { population }\end{array}$ & $54.2^{\dagger}$ & $\begin{array}{l}\text { History } \\
\text { taking }\end{array}$ & 81 \\
\hline Patel et $\mathrm{al}^{37}$ & Europe & UK & $\mathrm{CS}$ & $\begin{array}{l}03-01- \\
2020 \\
04-01- \\
2020\end{array}$ & to & $\begin{array}{l}\text { General } \\
\text { population }\end{array}$ & $45.6^{\dagger}$ & $\begin{array}{l}\text { Self- } \\
\text { reported } \\
\text { survey }\end{array}$ & 141 \\
\hline $\begin{array}{l}\text { Carignan et } \\
\mathrm{al}^{16}\end{array}$ & $\begin{array}{l}\text { North } \\
\text { America }\end{array}$ & Canada & $\begin{array}{l}\text { Retrospective } \\
\text { case-control } \\
\text { study }\end{array}$ & NA & & $\begin{array}{l}\text { General } \\
\text { population }\end{array}$ & $57.1^{\ddagger}$ & $\begin{array}{l}\text { Self- } \\
\text { reported } \\
\text { survey }\end{array}$ & 134 \\
\hline Lee et $\mathrm{al}^{30}$ & $\begin{array}{l}\text { North } \\
\text { America }\end{array}$ & Canada & $\mathrm{CS}$ & $\begin{array}{l}03-15- \\
2020 \\
04-06- \\
2020\end{array}$ & to & $\begin{array}{l}\text { General } \\
\text { population }\end{array}$ & $38^{\ddagger}$ & $\begin{array}{l}\text { Self- } \\
\text { reported } \\
\text { survey }\end{array}$ & 56 \\
\hline $\begin{array}{l}\text { Aggarwal et } \\
\mathrm{al}^{11}\end{array}$ & $\begin{array}{l}\text { North } \\
\text { America }\end{array}$ & $\overline{\mathrm{USA}}$ & $\mathrm{CS}$ & NA & & $\begin{array}{l}\text { Hospitalized } \\
\text { population }\end{array}$ & $67^{\ddagger}$ & $\begin{array}{l}\text { History } \\
\text { taking }\end{array}$ & 16 \\
\hline $\begin{array}{ll}\text { Dawson } & \text { et } \\
\mathrm{al}^{18} & \end{array}$ & $\begin{array}{l}\text { North } \\
\text { America }\end{array}$ & $\overline{\mathrm{USA}}$ & $\mathrm{CS}$ & NA & & $\begin{array}{l}\text { General } \\
\text { population }\end{array}$ & Unknown & $\begin{array}{l}\text { Self- } \\
\text { reported } \\
\text { survey }\end{array}$ & 42 \\
\hline Pinna et $\mathrm{al}^{39}$ & $\begin{array}{l}\text { North } \\
\text { America }\end{array}$ & $\overline{\mathrm{USA}}$ & $\begin{array}{l}\text { Retrospective } \\
\text { case series }\end{array}$ & $\begin{array}{l}03-01- \\
2020 \\
04-30- \\
2020\end{array}$ & to & $\begin{array}{l}\text { Hospitalized } \\
\text { population }\end{array}$ & $59.6^{\dagger}$ & $\begin{array}{l}\text { History } \\
\text { taking }\end{array}$ & 50 \\
\hline Yan et al ${ }^{57}$ & $\begin{array}{l}\text { North } \\
\text { America }\end{array}$ & USA & CS & $\begin{array}{l}03-03- \\
2020 \\
03-29- \\
2020\end{array}$ & to & $\begin{array}{l}\text { General } \\
\text { population }\end{array}$ & Unknown & $\begin{array}{l}\text { Self- } \\
\text { reported } \\
\text { survey }\end{array}$ & 59 \\
\hline Yan et al ${ }^{58}$ & $\begin{array}{l}\text { North } \\
\text { America }\end{array}$ & USA & $\begin{array}{l}\text { Retrospective } \\
\text { case series }\end{array}$ & $\begin{array}{l}03-03- \\
2020 \\
04-08- \\
2020\end{array}$ & to & $\begin{array}{l}\text { General } \\
\text { population }\end{array}$ & Unknown & $\begin{array}{l}\text { Self- } \\
\text { reported } \\
\text { survey }\end{array}$ & 128 \\
\hline Yan et $\mathrm{al}^{50}$ & $\begin{array}{l}\text { North } \\
\text { America }\end{array}$ & $\overline{\mathrm{USA}}$ & $\mathrm{CS}$ & $\begin{array}{l}03-09- \\
2020 \\
04-29- \\
2020\end{array}$ & to & $\begin{array}{l}\text { General } \\
\text { population }\end{array}$ & Unknown & $\begin{array}{l}\text { Self- } \\
\text { reported } \\
\text { survey }\end{array}$ & 46 \\
\hline $\begin{array}{ll}\text { Moein } & \text { et } \\
\mathrm{al}^{55} & \end{array}$ & $\begin{array}{l}\text { Middle } \\
\text { East }\end{array}$ & Iran & $\begin{array}{l}\text { Retrospective } \\
\text { case-control } \\
\text { study }\end{array}$ & $\begin{array}{l}03-21- \\
2020 \\
04-05- \\
2020\end{array}$ & to & $\begin{array}{l}\text { Hospitalized } \\
\text { population }\end{array}$ & $46.6^{\dagger}$ & $\begin{array}{l}\text { Validated } \\
\text { instrument }\end{array}$ & 60 \\
\hline $\begin{array}{ll}\text { Biadsee } & \text { et } \\
\mathrm{al}^{14} & \end{array}$ & $\begin{array}{l}\text { Middle } \\
\text { East }\end{array}$ & Israel & $\mathrm{CS}$ & NA & & $\begin{array}{l}\text { Non- } \\
\text { hospitalized } \\
\text { population }\end{array}$ & $36.3^{\dagger}$ & $\begin{array}{l}\text { Self- } \\
\text { reported } \\
\text { survey }\end{array}$ & 128 \\
\hline $\begin{array}{l}\text { Levinson et } \\
\mathrm{al}^{31}\end{array}$ & $\begin{array}{l}\text { Middle } \\
\text { East }\end{array}$ & Israel & $\mathrm{CS}$ & $\begin{array}{l}03-10- \\
2020 \\
03-23- \\
2020\end{array}$ & to & $\begin{array}{l}\text { Hospitalized } \\
\text { population }\end{array}$ & $34^{\ddagger}$ & $\begin{array}{l}\text { Self- } \\
\text { reported } \\
\text { survey }\end{array}$ & 42 \\
\hline $\begin{array}{ll}\text { Sakalli } & \text { et } \\
\mathrm{al}^{41} & \end{array}$ & $\begin{array}{l}\text { Middle } \\
\text { East }\end{array}$ & Turkey & $\mathrm{CS}$ & NA & & $\begin{array}{l}\text { General } \\
\text { population }\end{array}$ & $37.8^{\dagger}$ & $\begin{array}{l}\text { Self- } \\
\text { reported }\end{array}$ & 172 \\
\hline
\end{tabular}




\begin{tabular}{|c|c|c|c|c|c|c|c|c|}
\hline Sayin et al ${ }^{42}$ & $\begin{array}{l}\text { Middle } \\
\text { East }\end{array}$ & Turkey & $\begin{array}{l}\text { Retrospective } \\
\text { case-control } \\
\text { study }\end{array}$ & NA & $\begin{array}{l}\text { General } \\
\text { population }\end{array}$ & 37.8 & $\begin{array}{l}\text { Validated } \\
\text { survey }\end{array}$ & 64 \\
\hline
\end{tabular}

Abbreviations: COVID-19, coronavirus disease 2019; CS, cross-sectional; NA, not available

${ }^{\dagger}$ Mean age; ${ }^{\ddagger}$ Median age

\section{Quality assessment}

Quality assessment of the individual studies is demonstrated in Supplementary Table S1 Online. The mean overall score was 3.5, indicating overall low to moderate risk of procedure bias, and there were 29 and 26 studies with low and moderate risk of procedure bias, respectively. No study had a high risk of methodological bias because the prevalence of olfactory and/or gustatory dysfunction was similarly evaluated in patients. However, the studies with hospitalized, non-hospitalized, or healthcare worker populations that did not represent the general population were commonly evaluated as studies with a moderate risk of bias. Most individual studies were cross-sectional, which contains an implicit risk of bias if the number of patients omitted was not recorded accurately.

\section{The overall prevalences of olfactory and gustatory dysfunction in COVID-19 patients}

A total of 13,527 patients were identified for assessment of olfactory dysfunction in 55 studies. The prevalence of olfactory dysfunction in individual studies ranged from $5.1 \%$ to $99.0 \%$, and the prevalence was $51.4 \%$ in the random-effects model with severe inter-study heterogeneity (95\% confidence interval [CI]: $43.7 \%$, $59.1 \% ; 1^{2}=98.6 \%$; Supplementary Fig. S1a Online). Evaluation of gustatory dysfunction was identified in 46 included studies of 13,014 patients. The prevalence of gustatory dysfunction in individual studies ranged from $5.1 \%$ to $89.4 \%$, and the random-effects model demonstrated a $47.5 \%$ prevalence with severe inter-study heterogeneity (95\% Cl: 39.7\%, 55.3\%; $I^{2}=98.6 \%$; Supplementary Fig. S1b Online).

\section{Subgroup analyses according to the region}

The prevalences of olfactory and gustatory dysfunction of the four different regions were $25.3 \%$ and $19.4 \%$ in East Asia, $57.5 \%$ and $53.1 \%$ in Europe, $41.8 \%$ and $46.2 \%$ in North America, and $59.8 \%$ and $47.9 \%$ in the Middle East, respectively, with a significant difference among the regions (both $\mathrm{P}<0.001$; Fig. $2 \mathrm{a}$ and $2 \mathrm{~b}$ ). Post-hoc analysis revealed that the prevalence of olfactory dysfunction in East Asia was significantly lower than that in Europe or the Middle East $(P=0.001$ and $P=0.021$, respectively), and prevalence of gustatory dysfunction in East Asia was significantly lower than that in Europe or North America $(P=0.001$ and $P=0.048$, respectively). Considering the possibility that olfactory or gustatory dysfunction was not accurately recorded when the history taking was used as the evaluation method, an analysis of variance (ANOVA) was performed without the studies conducted with history taking as the evaluation method, and the results also showed a significant difference among the regions $(P=0.005$ and $P<0.001$, respectively; Supplementary Fig. S2a and S2b Online). The regional prevalences of olfactory and gustatory dysfunction are shown in Fig. 3.

\section{Subgroup analyses according to the time of enrollment}


The time of enrollment was clarified in 29 out of 55 studies. The time of enrollment in the included studies ranged from January 16, 2020 to May 2, 2020. The beginning date of the time of enrollment in the included studies ranged from January 16, 2020 to April 6, 2020, and the end date ranged from February 9, 2020 to May 2 , 2020. After calculating the median date (mid-date) between the beginning and end date of the time of enrollment, the individual studies were categorized into three groups: $1^{\text {st }}$ period (mid-date February 2, 2020 to March 17, 2020), $2^{\text {nd }}$ period (mid-date March 20, 2020 to March 29, 2020), and $3^{\text {rd }}$ period (mid-date March 30 , 2020 to April 9,2020). The numbers of included studies of olfactory and gustatory dysfunction in each period were $n=10$ and $n=8$ for the $1^{\text {st }}$ period, $n=11$ and $n=9$ for the $2^{\text {nd }}$ period, and $n=8$ and $n=6$ for the $3^{\text {rd }}$ period, respectively. The prevalences of olfactory and gustatory dysfunction for the three periods were $39.5 \%$ and $40.9 \%$ for the $1^{\text {st }}$ period, $57.7 \%$ and $51.2 \%$ for the $2^{\text {nd }}$ period, and 49.0 and $40.5 \%$ for the $3^{\text {rd }}$ period, respectively; however, no significant difference was found with regard to the time of enrollment $(P=0.391$ and $P=0.778$; Fig. $4 a$ and $4 b)$. As the region can be a potential confounding factor, we performed ANOVA for the studies conducted in Europe $(n=16)$. The ANOVA of the studies from Europe demonstrated that there were significant differences in the prevalences of olfactory dysfunction among the three periods ( $P=0.013$; Fig. 4c); however, there was no significant difference in the prevalence of gustatory dysfunction (Fig. 4d). Post-hoc analysis revealed that the prevalence of olfactory dysfunction in the $2^{\text {nd }}$ period was significantly higher than that in the $1^{\text {st }}$ period $(P=0.046)$. Furthermore, the chronological difference among the studies from Europe was significant even when studies in which history taking was used as an evaluation method were omitted ( $P$ $=0.038$, Supplementary Fig. S3 Online). The chronological prevalences of olfactory and gustatory dysfunction are shown in Fig. 5.

\section{Subgroup analyses according to evaluation method}

The prevalences of olfactory and gustatory dysfunction according to the four different evaluation methods were $23.4 \%$ and $23.5 \%$ for history taking, $52.1 \%$ and $53.2 \%$ for self-reported surveys, 72.9 and $68.5 \%$ for validated surveys, and 69.2 and $48.4 \%$ for the validated instruments, respectively, and there was a significant difference among the regions (both $\mathrm{P}<0.001$, respectively; Fig. $6 \mathrm{a}$ and $6 \mathrm{~b}$ ). In a post-hoc analysis, the prevalence of olfactory dysfunction evaluated by history taking was lower than that evaluated by other methods (all $P<0.001$, respectively), and the prevalence evaluated by the self-reported survey was lower than that evaluated by validated survey $(P=0.033)$. In addition, the prevalence of gustatory dysfunction by history taking was lower than that evaluated by the self-reported survey, validated survey, and validated instrument $(\mathrm{P}$ $<0.001, \mathrm{P}<0.001$, and $\mathrm{P}=0.004$, respectively).

\section{Subgroup analyses according to the characteristics of the population}

The prevalences of olfactory and gustatory dysfunction according to the four population groups were $58.7 \%$ and $56.2 \%$ in the general population, $36.7 \%$ and $28.3 \%$ in hospitalized patients, $52.3 \%$ and $51.1 \%$ in nonhospitalized patients, and $48.94 \%$ and $51.52 \%$ in health care workers, respectively (Fig. $7 \mathrm{a}$ and $7 \mathrm{~b}$ ). Interestingly, a significant difference was found in the prevalence of gustatory dysfunction depending on the characteristics of the population $(P=0.013)$ but not in that of olfactory dysfunction $(P=0.173)$. Post-hoc analysis showed that the prevalence of gustatory dysfunction of the hospitalized patients was significantly lower than that of the general population $(P=0.030)$ 


\section{Assessment of publication bias}

The funnel plot demonstrated potential publication bias in the analysis (Supplementary Fig. S4a and S4b Online). In Egger's test, there was a potential publication bias for the prevalences of olfactory and gustatory dysfunction $(P=0.031, P=0.028)$. However, asymmetry in the funnel plots may be attributed to the various factors that elicited different prevalences, such as region, time of enrollment, and evaluation method, rather than publication bias.

\section{Discussion}

Olfactory and gustatory dysfunction were not recognized as typical symptoms of COVID-19 in the early phase of virus' spread. However, as olfactory and gustatory dysfunction were frequently found in patients with COVID-19, these symptoms became significant. Furthermore, as a previous study reported, $17 \%$ of COVID-19 patients with anosmia were otherwise asymptomatic, meaning that isolated olfactory or gustatory dysfunction could be used as potential early indicators of SARS-CoV-2 infection during the COVID-19 pandemic. ${ }^{59}$ Possible mechanisms of olfactory dysfunctions in COVID-19 patients are conductive anosmia, disruption of olfactory epithelium following local infection, and retrograde propagation to higher-order neurons in the olfactory pathway. ${ }^{60}$ However, there is limited evidence to conclusively determine the mechanism of olfactory dysfunction in COVID-19. ${ }^{60}$ Considering gustatory dysfunction in COVID-19, it is unclear whether gustatory dysfunction is a distinct clinical feature of SARS-CoV-2 or occurs secondary to olfactory dysfunction. Although olfactory and gustatory dysfunction were noted frequently in COVID-19, the prevalences of olfactory and gustatory dysfunction were variable among previous studies. In this meta-analysis, subgroup analysis was performed to explain the variability of the prevalences of olfactory and gustatory dysfunction among patients with COVID-19.

In this meta-analysis, the prevalences of olfactory and gustatory dysfunction in COVID-19 patients were $51.4 \%$ and $47.5 \%$, with severe inter-study heterogeneity (both $\mathrm{I}^{2}=98.6 \%$, respectively), respectively. We performed subgroup analysis based on region, time of enrollment, demographics, and the evaluation method to explain the inter-study heterogeneity.

As we hypothesized, the prevalences of olfactory and gustatory dysfunction were different among the four geographical regions. The prevalence of olfactory dysfunction in East Asia was significantly lower than that in Europe or the Middle East and prevalence of gustatory dysfunction in East Asia was significantly lower than that in Europe and North America. In the subgroup analysis on the time of enrollment, there was no significant difference among the three periods. However, considering the spread of the virus occurred regionally and chronologically, the regional factor might be a potential confounding factor. In an ANOVA of the studies from Europe alone, there were significant differences in the prevalences of olfactory dysfunction among the three time period groups, indicating that a genetic mutation of virus in the same region may have affected the prevalence of olfactory dysfunction. The prevalences of olfactory dysfunction of the all regions were $39.5 \%$ for the $1^{\text {st }}$ period, $57.7 \%$ for the $2^{\text {nd }}$ period, and $49.0 \%$ for the $3^{\text {rd }}$ period, which was a similar tendency compared to that of Europe: $45.2 \%$ for the $1^{\text {st }}$ period, $65.4 \%$ for the $2^{\text {nd }}$ period, and $59.0 \%$ for the $3^{\text {rd }}$ period. Interestingly, olfactory dysfunction increased from the $1^{\text {st }}$ to $2^{\text {nd }}$ period but slightly decreased from the $2^{\text {nd }}$ to $3^{\text {rd }}$ period. 
Because the included studies were performed with various evaluation methods and populations, we carried out further subgroup analyses on the evaluation methods and population group to explain the heterogeneity. In subgroup analysis on the evaluation methods, the prevalences of olfactory and gustatory dysfunction evaluated by history taking were lower than those by other evaluation methods. In contrast to survey or objective test, simple history taking may have a risk of omitting questions about olfactory and gustatory dysfunction. The chemosensory function of these patients was often regarded as normal, leading to a low prevalence of olfactory and gustatory dysfunction. Therefore, we confirmed the results of the subgroup analysis on the geographical region and the time of enrollment by omitting studies in which history taking was used as the evaluation method, and we found that it still showed a statistical significance. In subgroup analysis on the population group, interestingly, a significant difference was found in the prevalence of gustatory dysfunction depending on population characteristics but not in that of olfactory dysfunction. In a post-hoc analysis, the prevalence of gustatory dysfunction of the hospitalized patients was lower than that of the general population, which may be attributed to the higher rate of the history taking as the evaluation method in hospitalized patients than that in the general population ( $46.7 \%$ vs. $6.9 \%$, respectively).

There are some possible explanations for the regional and chronological differences in olfactory and gustatory dysfunction in COVID-19-first, the ethnic differences in the frequency variants of angiotensin-converting enzyme 2 (ACE2). As previous studies indicate, ACE2 is a possible host receptor of SARS-CoV-2. ${ }^{61,62}$ Variants of ACE2 may affect the course of infection, including susceptibility and symptoms depending on the expression level and pattern of ACE2 in different tissues. ${ }^{63}$ In a previous study, presence of a difference in variants of ACE2 according to geographical and ethnic factors was demonstrated, ${ }^{63}$ and it is assumed that the difference in variants of ACE2 expressed in olfactory epithelial cells according to populations from different geographical regions can influence the prevalence of olfactory and gustatory dysfunction. Second, phylogenetic mutation may contribute to regional and chronological differences. As the prevalence of olfactory dysfunction was significantly different according to time of enrollment in subgroup analysis with the studies from European countries, the ethnic differences may not be sufficient to explain the chronological differences in the prevalences of olfactory dysfunction. Recent studies reported that SARS-CoV-2 has rapidly attained mutations as a typical coronavirus, allowing for tracking its spread. ${ }^{64,65}$ The prevalence of $S$ type and L type of SARS-CoV-2 were $3.7 \%$ and $96.3 \%$ in viral isolates in Wuhan, respectively, yet viral isolates outside of Wuhan were $38.4 \% \mathrm{~S}$ type and $61.3 \% \mathrm{~L}$ type. ${ }^{65}$ Furthermore, the mutation may cause regional differences in virus type. For instance, a previous study revealed that the B1 clade is dominant in the West Coast of the United States, while the A2a clade, which seems to have spread through Europe and Italy, is dominant in the East Coast of the United States. ${ }^{66}$ In addition to the regional differences, the expanding phylogenetic diversity can induce a chronologic difference in the type of SARS-CoV-2. A previous study revealed the global transition of the SARS-CoV-2 spike protein from the original D614 to the G614 variant. ${ }^{67}$ To be specific, through March 1 , 2020, the G614 variant was rare outside Europe; however, it increased in frequency worldwide by the end of March. ${ }^{67}$ As the virus types and genetic mutations were different regionally and chronologically, ${ }^{65-67}$ the influence of SARS-CoV-2 on the olfactory epithelium may have differed according to virus type and genetic mutation. Lastly, heterogeneity in the study designs may have caused different prevalences of olfactory and gustatory dysfunction. The study populations and evaluation methods were variable in the individual studies. As shown in the results, evaluation method may lead to different prevalence. To reduce the confounding effect of the evaluation method, we performed a subgroup analysis without the studies in which history taking was 
used as an evaluation method. However, the other three methods may also have had differences, although statistical significance was not found. In addition, different characteristics of populations might affect the prevalences in individual studies.

In conclusion, olfactory and gustatory dysfunction are commonly reported in patients with COVID-19 and noted as significant symptoms; however, the prevalences are variable. This meta-analysis revealed that regional and chronological differences in the prevalences of olfactory and gustatory dysfunction may explain the inter-study heterogeneity and indicate that the course of infection may differ according to ethnic and demographic characteristics.

\section{Methods}

\section{Search strategy}

A comprehensive search of PUBMED, EMBASE, and Scopus databases following the Preferred Reporting Items for Systematic Reviews and Meta-Analyses (PRISMA) guideline was carried out up to July $9^{\text {th }}, 2020 .{ }^{68}$ Two authors (S.C.H, J.Y.K) independently performed literature searches to identify candidate studies for the metaanalysis using the terms: ("olfact*" OR "smell" OR "anosmia" OR "hyposmia") AND COVID-19. Only studies published in English were selected.

\section{Selection of studies}

The two authors independently screened abstracts and titles of studies identified by the search strategy. Studies that did not satisfy eligibility criteria were discarded; then, eligibility was evaluated in the full-text format. The inclusion criteria of the present systematic review and meta-analysis were as follows: (1) the article reports on prevalence of olfactory or gustatory dysfunction in patients with COVID-19 (2) prevalence of olfactory or gustatory dysfunction are separately reported. The following types of studies were excluded: (1) multicenter studies, including different continents (e.g., Europe and Asia) (2) studies lacking full text (e.g., only abstracts).

\section{Data extraction}

Data from included studies were extracted into standardized forms and were independently confirmed by the two authors. For each article, the following information was collected: the name of the first author, year of publication, study design, country where the study was conducted, time patients were enrolled, age, sample size, number of patients with olfactory dysfunction, number of patients with gustatory dysfunction, evaluation method of olfactory dysfunction and/or gustatory function, and the characteristics of the population (general population, hospitalized population, non-hospitalized population, or healthcare workers population). The regions where the individual studies were conducted were categorized into: East Asia, Europe, North America, Middle East, Latin America, and Africa. The evaluation method was classified into history taking, self-reported survey, validated survey, and validated instrument. The validated surveys were designated as surveys with structured questions about olfactory and/or gustatory dysfunction. The validated instrument included evaluation with psychophysical function tests such as Sniffin' Sticks, UPSIT, and taste test. 
Risk of bias was evaluated using a quality assessment checklist for prevalence studies based on nine domains: representation of the national population, representation of the target population, random selection, likelihood of nonresponse, directly collected data from the subject, case definition, validity of the instrument of measurement, similarity in mode of data collection for all subjects, and presence of numerators and denominators in the parameters of interest. ${ }^{69}$ Each item was graded as 0 for low risk or 1 for high risk, and the summation of values rated to evaluate the risk of bias were $0-3,4-6$, and 7-9 for low, moderate, and high risk of bias, respectively.

\section{Statistical analysis}

Calculating the data extracted from each study, the weighted summary prevalence of olfactory and gustatory dysfunction was estimated using a Freeman-Tukey transformation with models based on random-effects assumptions. ${ }^{70}$ Because prevalence would be influenced by the spectrum of populations and the evaluation method of olfactory or gustatory dysfunction in the individual studies, we expected a significant heterogeneity across the included studies. Therefore, we selected a random-effects model to give more conservative estimates. A meta-analysis of variance compared the prevalence of olfactory and gustatory dysfunction according to regional, chronological, demographic, and methodologic factors, respectively. Post-hoc analysis was carried out using Tukey's test for the results of ANOVA. To assess heterogeneity across the included studies, the Cochran Q statistic test and the $\mathrm{I}^{2}$ test were carried out. A funnel plot and Egger's test were used to evaluate potential publication bias. All analyses were conducted in R for Windows version 3.6.1 by using the "meta" and "metaphor" packages (R Foundation for Statistical Computing, Vienna, Austria). A P-value $<0.05$ was considered statistically significant.

\section{Data Availability}

No datasets were generated or analyzed during the current study.

\section{Declarations}

Acknowledgements: Not applicable.

\section{Authors' Contributions}

J.W.K. and J.Y.K. designed this study. S.C.H. and J.Y.K. independently reviewed the individual studies and extracted data. H.D.J and J.Y.K. performed the quality assessment for the included studies. J.Y.K. implemented data analysis and visualization. J.W.K and J.Y.K drafted the original manuscript. J.W.K and S.W.C reviewed the manuscript.

\section{Additional information}

Conflict of interest: The authors have no conflicts of interest to declare or any source of funding related to this study. 
Funding: None

\section{References}

1 Wu, Z. \& McGoogan, J. M. Characteristics of and important lessons from the coronavirus disease 2019 (COVID-19) outbreak in China: summary of a report of 72314 cases from the Chinese Center for Disease Control and Prevention. JAMA. 323, 1239-1242 (2020).

2 Gengler, I., Wang, J. C., Speth, M. M. \& Sedaghat, A. R. Sinonasal pathophysiology of SARS-CoV-2 and COVID-19: A systematic review of the current evidence. Laryngoscope Investig Otolaryngol. 5, 354-359, doi:10.1002/lio2.384 (2020).

3 Zou, L. et al. SARS-CoV-2 viral load in upper respiratory specimens of infected patients. N Engl J Med. 382, 1177-1179 (2020).

4 Tong, J. Y., Wong, A., Zhu, D., Fastenberg, J. H. \& Tham, T. The Prevalence of Olfactory and Gustatory Dysfunction in COVID-19 Patients: A Systematic Review and Meta-analysis. Otolaryngol Head Neck Surg. 163, 3-11, doi:10.1177/0194599820926473 (2020).

5 Kim, G.u. et al. Clinical characteristics of asymptomatic and symptomatic patients with mild COVID-19. Clin Microbiol Infect., doi: 10.1016/j.cmi.2020.04.040 (2020).

6 Lee, Y., Min, P., Lee, S. \& Kim, S.-W. Prevalence and duration of acute loss of smell or taste in COVID-19 patients. J Korean Med Sci. 35 (2020).

$7 \quad$ Liang, Y. et al. Neurosensory dysfunction: a diagnostic marker of early COVID-19. Int J Infect Dis., doi: 10.1016/j.jijid.2020.06.086 (2020).

8 Mao, L. et al. Neurologic manifestations of hospitalized patients with coronavirus disease 2019 in Wuhan, China. JAMA neurol. 77, 683-690 (2020).

9 Noh, J. Y. et al. Asymptomatic infection and atypical manifestations of COVID-19: comparison of viral shedding duration. J Infect., doi: 10.1016/j.jinf.2020.05.035(2020).

10 Abalo-Lojo, J. M., Pouso-Diz, J. M. \& Gonzalez, F. Taste and Smell Dysfunction in COVID-19 Patients. Ann Otol Rhinol Laryngol., doi: 10.1177/0003489420932617 (2020).

11 Aggarwal, S. et al. Clinical features, laboratory characteristics, and outcomes of patients hospitalized with coronavirus disease 2019 (COVID-19): Early report from the United States. Diagnosis 7, 91-96 (2020).

12 Altin, F., Cingi, C., Uzun, T. \& Bal, C. Olfactory and gustatory abnormalities in COVID-19 cases. Eur Arch Otorhinolaryngol., 1-7 (2020).

13 Beltrán-Corbellini, Á. et al. Acute-onset smell and taste disorders in the context of COVID-19: a pilot multicentre polymerase chain reaction based case-control study. Eur J neurol., doi: 10.1111/ene.14273 (2020). 
14 Biadsee, A. et al. Olfactory and Oral Manifestations of COVID-19: Sex-Related Symptoms-A Potential Pathway to Early Diagnosis. Otolaryngol Head Neck Surg., doi: 10.1177/0194599820934380 (2020).

15 Brandstetter, S. et al. Symptoms and immunoglobulin development in hospital staff exposed to a SARSCoV-2 outbreak. Pediatr Allergy Immunol., doi: 10.1111/pai.13278 (2020).

16 Carignan, A. et al. Anosmia and dysgeusia associated with SARS-CoV-2 infection: an age-matched case- control study. CMAJ, doi: 10.1503/cmaj.200869 (2020).

17 Chua, A. J. K., Chan, E. C. Y., Loh, J. \& Charn, T. C. Acute olfactory loss is specific for Covid-19 at the Emergency Department. Ann Emerg Med., doi: 10.1016/j.annemergmed.2020.05.015. (2020).

18 Dawson, P. et al. Loss of Taste and Smell as Distinguishing Symptoms of COVID-19. Clin Infect Dis., doi: 10.1093/cid/ciaa799 (2020).

19 De Maria, A., Varese, P., Dentone, C., Barisione, E. \& Bassetti, M. High prevalence of olfactory and taste disorder during SARS-CoV-2 infection in outpatients. J Med Virol., doi: 10.1002/jmv.25995. (2020).

20 Dell'Era, V. et al. Smell and taste disorders during COVID-19 outbreak: A cross-sectional study on 355 patients. Head Neck., doi: 10.1002/hed.26288 (2020).

21 Freni, F. et al. Symptomatology in head and neck district in coronavirus disease (COVID-19): A possible neuroinvasive action of SARS-CoV-2. Am J Otolaryngol., doi: 10.1016/j.amjoto.2020.102612. (2020).

22 Gelardi, M., Trecca, E., Cassano, M. \& Ciprandi, G. Smell and taste dysfunction during the COVID-19 outbreak: a preliminary report. Acta Biomed. 91, 230-231 (2020).

23 Iravani, B. et al. Relationship between odor intensity estimates and COVID-19 prevalence prediction in a Swedish population. Chem Senses., doi: 10.1093/chemse/bjaa034 (2020).

24 Izquierdo-Domínguez, A. et al. Smell and taste dysfunctions in COVID-19 are associated with younger age in ambulatory settings-a multicenter cross-sectional study. J Investig Allergol Clin Immunol., doi: 10.18176/jiaci.0595 (2020).

25 Karadaş, Ö., Öztürk, B. \& Sonkaya, A. R. A prospective clinical study of detailed neurological manifestations in patients with COVID-19. Neurol Sci., 1-5 (2020).

26 Lagi, F. et al. Early experience of an infectious and tropical diseases unit during the coronavirus disease (COVID-19) pandemic, Florence, Italy, February to March 2020. Euro Surveill. 25, 2000556 (2020).

27 Lechien, J. R. et al. Objective olfactory evaluation of self-reported loss of smell in a case series of 86 COVID-19 patients. Head Neck., doi: 10.1002/hed.26279 (2020).

28 Lechien, J. R. et al. Olfactory and gustatory dysfunctions as a clinical presentation of mild-to-moderate forms of the coronavirus disease (COVID-19): a multicenter European study. Eur Arch Otorhinolaryngol., 1-11 (2020). 
29 Lechien, J. R. et al. Clinical and epidemiological characteristics of 1,420 European patients with mild-tomoderate coronavirus disease 2019. J Intern Med., doi: 10.1111/joim.13089 (2020).

30 Lee, D. J. et al. Self-reported anosmia and dysgeusia as key symptoms of COVID-19. CJEM., 1-19 (2020).

31 Levinson, R. et al. Time course of anosmia and dysgeusia in patients with mild SARS-CoV-2 infection. Infect Dis. 52, 600-602 (2020).

32 Liguori, C. et al. Subjective neurological symptoms frequently occur in patients with SARS-CoV2 infection. Brain Behav Immun., doi: 10.1016/j.bbi.2020.05.037 (2020).

33 Luers, J. C. et al. Olfactory and gustatory dysfunction in Coronavirus disease 19 (COVID-19). Clin Infect Dis., doi: 10.1093/cid/ciaa525 (2020).

34 Meini, S., Suardi, L. R., Busoni, M., Roberts, A. T. \& Fortini, A. Olfactory and gustatory dysfunctions in 100 patients hospitalized for COVID-19: sex differences and recovery time in real-life. Eur Arch Otorhinolaryngol., 1 (2020).

35 Mercante, G. et al. Prevalence of Taste and Smell Dysfunction in Coronavirus Disease 2019. JAMA Otolaryngol Head Neck Surg., doi: 10.1001/jamaoto.2020.1155. (2020).

36 Paderno, A. et al. Olfactory and Gustatory Outcomes in COVID-19: A Prospective Evaluation in Nonhospitalized Subjects. Otolaryngol Head Neck Surg., doi: 10.1177/0194599820939538 (2020).

37 Patel, A. et al. New onset anosmia and ageusia in adult patients diagnosed with SARS-CoV-2. Clin Microbiol Infect., doi: 10.1016/j.cmi.2020.05.026 (2020).

38 Petrocelli, M. et al. Remote psychophysical evaluation of olfactory and gustatory functions in earlystage coronavirus disease 2019 patients: the Bologna experience of 300 cases. J Laryngol Otol., 1-12 (2020).

39 Pinna, P. et al. Neurological manifestations and COVID-19: Experiences from a tertiary care center at the Frontline. J Neurol Sci., doi: 10.1016/j.jns.2020.116969 (2020).

40 Renaud, M. et al. Acute smell and taste loss in outpatients: all infected with SARS-CoV-2? Rhinology., doi: 10.4193/Rhin20.199 (2020).

41 Sakalli, E. et al. Ear nose throat-related symptoms with a focus on loss of smell and/or taste in COVID19 patients. Am J Otolaryngol., doi: 10.1016/j.amjoto.2020.102622 (2020).

42 Sayin, I., Yaşar, K. K. \& Yazici, Z. M. Taste and Smell Impairment in COVID-19: An AAO-HNS Anosmia Reporting Tool-Based Comparative Study. Otolaryngol Head Neck Surg., doi: 10.1177/0194599820931820 (2020).

43 Sierpiński, R. et al. Sex differences in the frequency of gastrointestinal symptoms and olfactory or taste disorders among 1,942 non-hospitalized patients with COVID-19. Pol Arch Intern Med., doi: 10.20452/pamw.15414 (2020).

Page $15 / 25$ 
44 Tostmann, A. et al. Strong associations and moderate predictive value of early symptoms for SARSCoV-2 test positivity among healthcare workers, the Netherlands, March 2020. Euro surveill., 25, 2000508 (2020).

45 Tsivgoulis, G. et al. Quantitative evaluation of olfactory dysfunction in hospitalized patients with Coronavirus [2](COVID-19). J Neurol., 1 (2020).

46 Vacchiano, V. et al. Early neurological manifestations of hospitalized COVID-19 patients. Neurol Sci., 1-3 (2020).

47 Vaira, L. A. et al. Objective evaluation of anosmia and ageusia in COVID-19 patients: Single-center experience on 72 cases. Head neck. 42, 1252-1258 (2020).

48 Vaira, L. A. et al. Olfactory and gustatory function impairment in COVID-19 patients: Italian objective multicenter-study. Head Neck., doi: 10.1002/hed.26269 (2020).

49 Vaira, L. A. et al. Validation of a self-administered olfactory and gustatory test for the remotely evaluation of COVID-19 patients in home quarantine. Head Neck., doi: 10.1002/hed.26228 (2020).

50 Yan, C. H., Prajapati, D. P., Ritter, M. L. \& DeConde, A. S. Persistent Smell Loss Following Undetectable SARS-CoV-2. Otolaryngol Head Neck Surg., doi: 10.1177/0194599820934769. (2020).

51 Zayet, S. et al. Contribution of anosmia and dysgeusia for diagnostic of COVID-19 in outpatients. Infection., 1 (2020).

52 Zayet, S. et al. Clinical features of COVID-19 and influenza: a comparative study on Nord Franche-Comte cluster. Microbes and infection (2020).

53 Chung, T. W.-H. et al. Olfactory Dysfunction in Coronavirus Disease 2019 Patients: Observational Cohort Study and Systematic Review. Open forum Infect Dis. 7, doi:10.1093/ofid/ofaa199 (2020).

54 Hintschich, C. A. \& Wenzel, J. J. Psychophysical tests reveal impaired olfaction but preserved gustation in COVID-19 patients., Int Forum Allergy Rhinol., doi:10.1002/alr.22655 (2020).

55 Moein, S. T. et al. Smell dysfunction: a biomarker for COVID-19. Int Forum Allergy Rhinol. 10, 944-950, doi:10.1002/alr.22587 (2020).

56 Paderno, A., Schreiber, A. \& Grammatica, A. Smell and taste alterations in COVID-19: a cross-sectional analysis of different cohorts. Int Forum Allergy Rhinol. 10, 955-962, doi:10.1002/alr.22610 (2020).

57 Yan, C. H. \& Faraji, F. Association of chemosensory dysfunction and COVID-19 in patients presenting with influenza-like symptoms. Int Forum Allergy Rhinol. 10, 806-813, doi:10.1002/alr.22579 (2020).

58 Yan, C. H., Faraji, F., Prajapati, D. P., Ostrander, B. T. \& DeConde, A. S. Self-reported olfactory loss associates with outpatient clinical course in COVID-19. Int Forum Allergy Rhinol. 10, 821-831, doi:10.1002/alr.22592 (2020). 
59 Hopkins, C., Surda, P. \& Kumar, N. Presentation of new onset anosmia during the COVID-19 pandemic. Rhinology. 10 (2020).

60 Han, A. Y., Mukdad, L., Long, J. L. \& Lopez, I. A. Anosmia in COVID-19: Mechanisms and Significance. Chem senses. doi:10.1093/chemse/bjaa040 (2020).

61 Lu, R. et al. Genomic characterisation and epidemiology of 2019 novel coronavirus: implications for virus origins and receptor binding. Lancet. 395, 565-574 (2020).

62 Zhou, P. et al. A pneumonia outbreak associated with a new coronavirus of probable bat origin. Nature. 579, 270-273 (2020).

63 Cao, Y. et al. Comparative genetic analysis of the novel coronavirus (2019-nCoV/SARS-CoV-2) receptor ACE2 in different populations. Cell Discov. 6, 1-4 (2020).

64 Hadfield, J. et al. Nextstrain: real-time tracking of pathogen evolution. Bioinformatics. 34, 4121-4123 (2018).

65 Tang, X. et al. On the origin and continuing evolution of SARS-CoV-2. Nat/ Sci Rev., doi: 10.1093/nsr/nwaa036 (2020).

66 Brufsky, A. Distinct Viral Clades of SARS-CoV-2: Implications for Modeling of Viral Spread. Journal of medical virology. J Med Virol., doi: 10.1002/jmv.25902. (2020).

67 Korber, B. et al. Tracking changes in SARS-CoV-2 Spike: evidence that D614G increases infectivity of the COVID-19 virus. Cell., doi: 10.1016/j.cell.2020.06.043 (2020).

68 Liberati, A. et al. The PRISMA statement for reporting systematic reviews and meta-analyses of studies that evaluate health care interventions: explanation and elaboration. J Clin Epidemiol. 62, e1-e34 (2009).

69 Hoy, D. et al. Assessing risk of bias in prevalence studies: modification of an existing tool and evidence of interrater agreement. J Clin Epidemiol. 65, 934-939 (2012).

70 Freeman, M. F. \& Tukey, J. W. Transformations related to the angular and the square root. The Annals of Mathematical Statistics, 607-611 (1950).

\section{Figures}


Fig.1

\begin{tabular}{|l|l|}
$\begin{array}{c}\text { Records identified through } \\
\text { database searching (Pubmed, } \\
\text { Embase, Scopus) ( } \mathrm{n}=943)\end{array}$ & $\begin{array}{l}\text { Records excluded }(\mathrm{n}=621) \\
\text { Duplicates: } 509 \\
\text { Review article: } 112\end{array}$ \\
\hline Full-text articles assessed for eligibility \\
( $\mathrm{n}=81$ )
\end{tabular}

\section{Figure 1}

Study selection diagram 
a

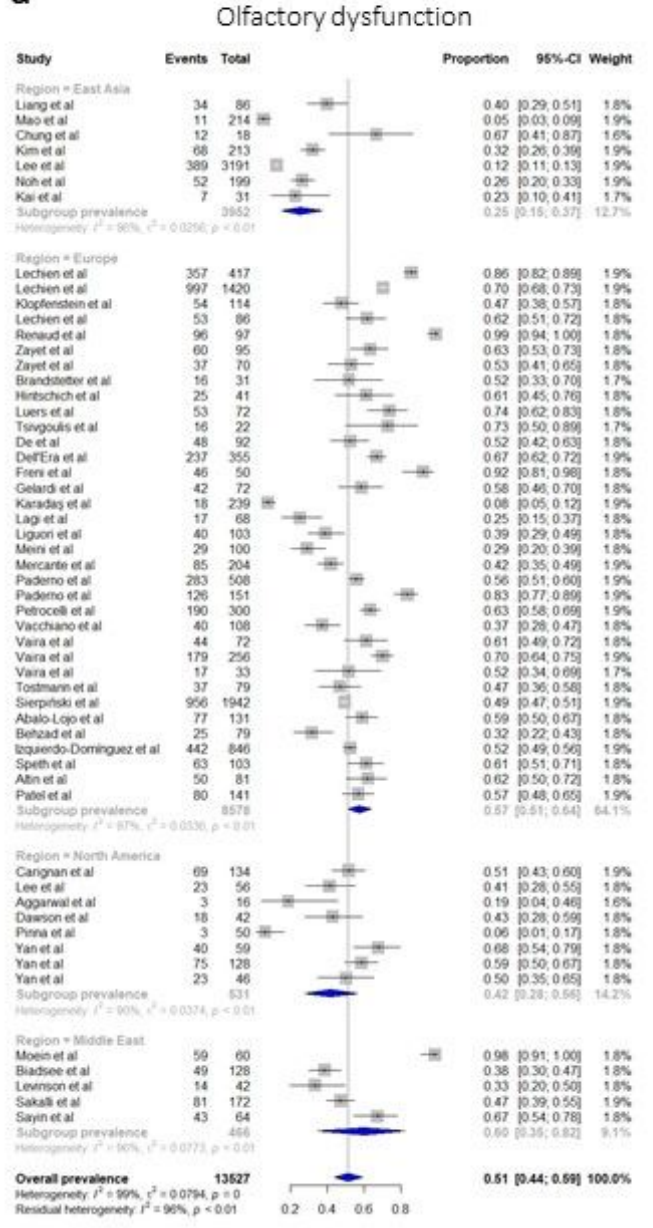

b

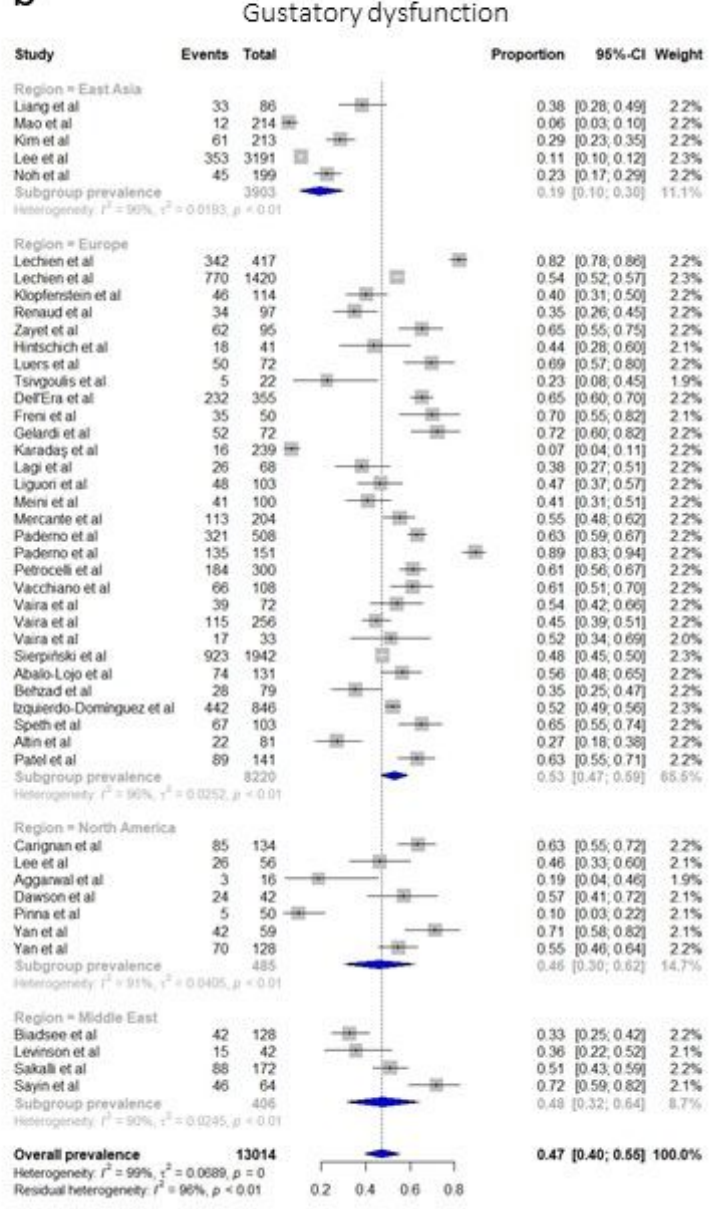

Figure 2

Subgroup analysis on region. (a) Forest plot meta-analysis of the prevalences of olfactory dysfunction of four regions (East Asia, Europe, North America, and Middle East) showed 25.3\%, 57.5\%, 41.8\%, and 59.8\% pooled subgroup prevalence in the random-effect model, respectively $(P<0.001$ for subgroup difference). (b) Forest plot meta-analysis of the prevalences of gustatory dysfunction of four regions (East Asia, Europe, North America, and Middle East) showed $19.4 \%, 53.1 \%, 46.2 \%$, and $47.9 \%$ pooled subgroup prevalence in the random-effect model, respectively ( $P<0.001$ for subgroup difference). The diamonds represent pooled 
prevalence with 95\% confidence interval, and the estimates of individual studies are represented as squares, with $95 \%$ confidence intervals represented as horizontal lines.

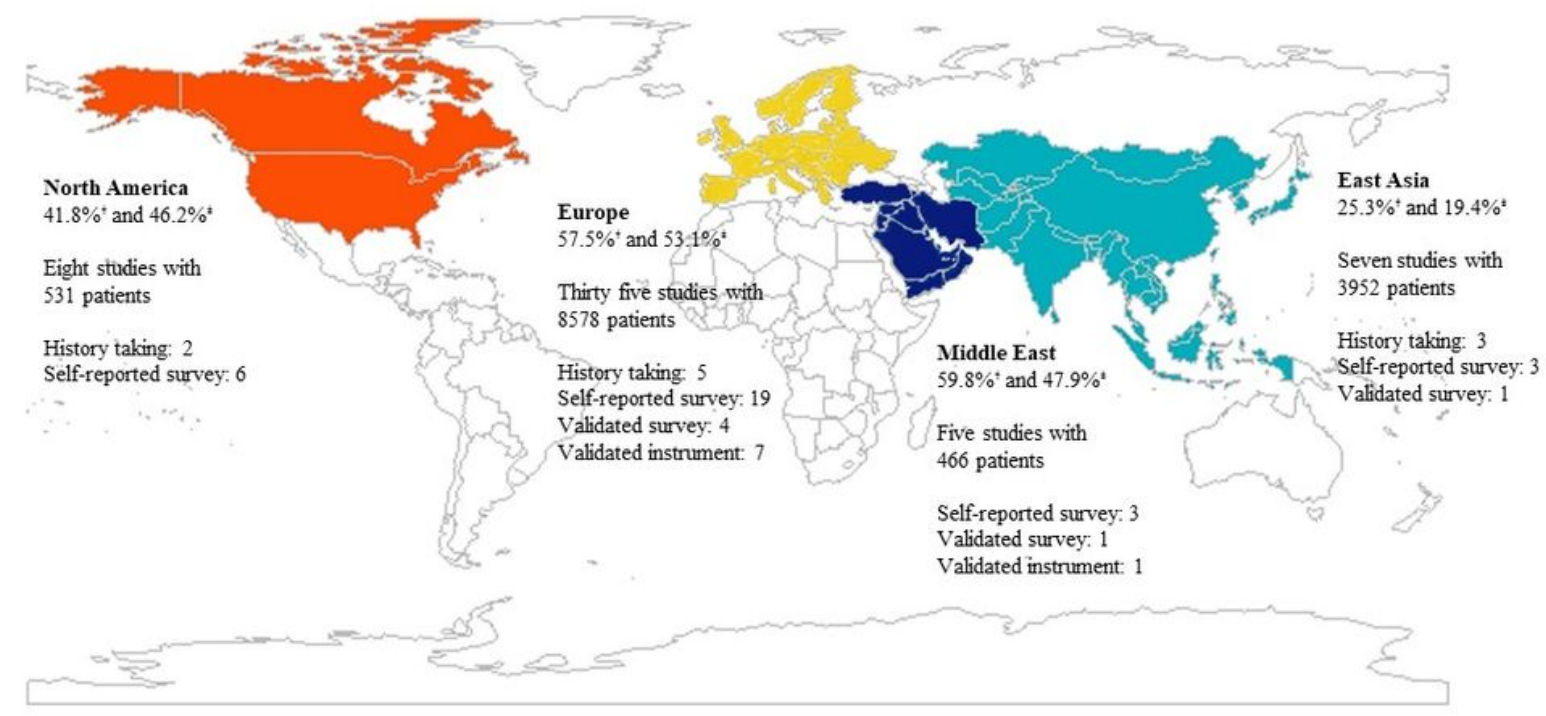

\section{Figure 3}

World map of the prevalences of olfactory and gustatory dysfunction in coronavirus disease 2019 patients. The colored regions indicate the geographically classified regions in this study (aqua blue: East Asia, yellow: Europe, red: North America, navy: Middle East). The prevalences of olfactory and gustatory dysfunction, number of included studies and patients, and number of studies according to the evaluation method are presented for each region (tolfactory and łgustatory dysfunction). Note: The designations employed and the presentation of the material on this map do not imply the expression of any opinion whatsoever on the part of Research Square concerning the legal status of any country, territory, city or area or of its authorities, or concerning the delimitation of its frontiers or boundaries. This map has been provided by the authors. 
a

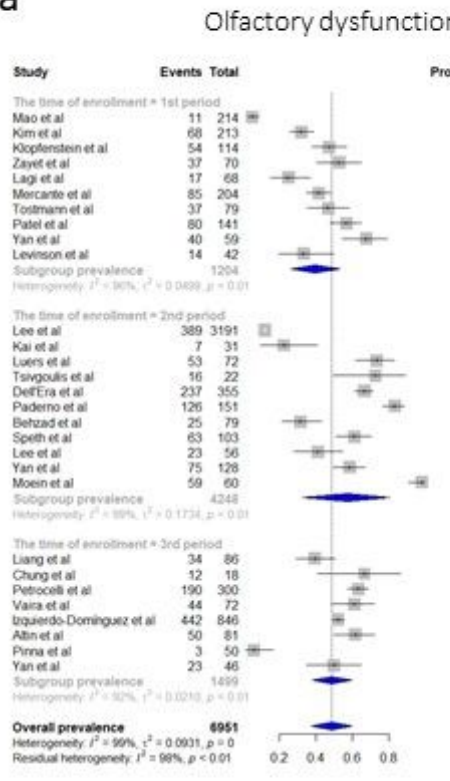

C

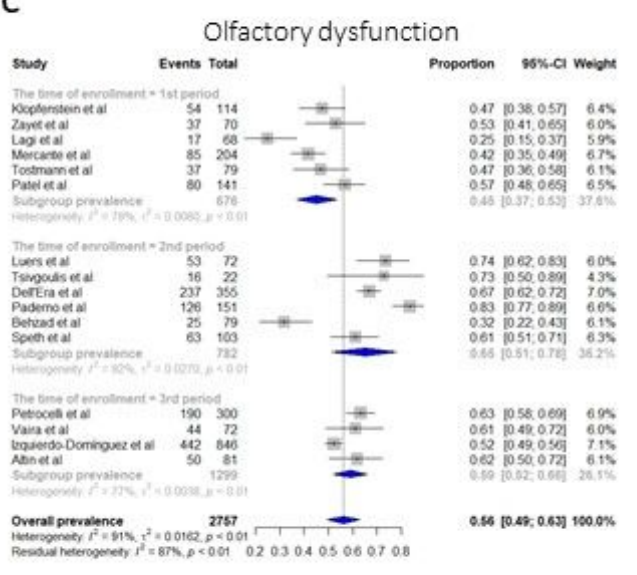

b

Gustatory dysfunction

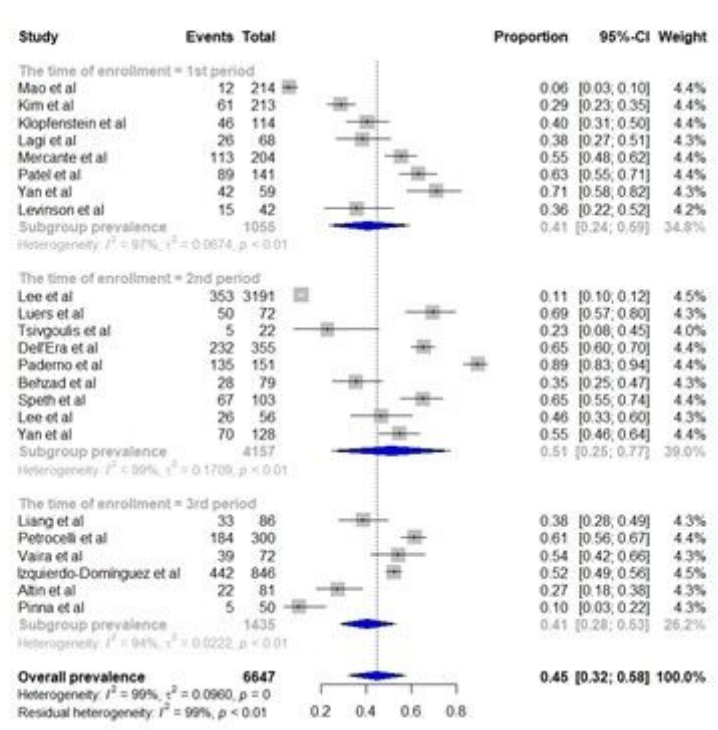

d

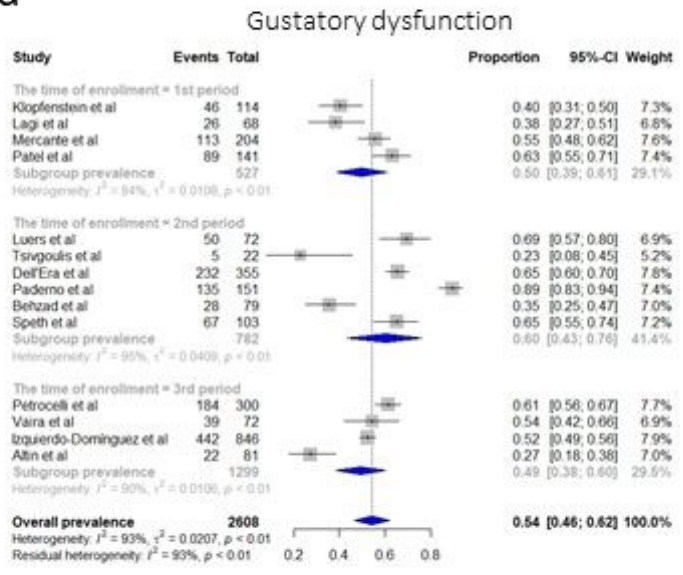

\section{Figure 4}

Subgroup analysis on the time of enrollment. The time of enrollment was clarified in 29 out of 55 studies. After calculating the median date (mid-date) between beginning and end date of the time of enrollment, the individual studies were categorized into three groups: 1st period (mid-date February 2, 2020 to March 17, 2020), 2nd period (mid-date March 20, 2020 to March 29, 2020), and 3rd period (mid-date March 30, 2020 to April 9, 2020). (a) Forest plot meta-analysis of the prevalence of olfactory dysfunction of the three periods showed $39.5 \%, 57.7 \%$, and $49.0 \%$ pooled subgroup prevalence in the random-effect model, respectively $(P=$ 0.391 for subgroup difference). (b) Forest plot meta-analysis of the prevalence of gustatory dysfunction of the 
three periods showed $40.9 \%, 51.2 \%$, and $40.5 \%$ pooled subgroup prevalence in the random-effect model, respectively ( $P=0.778$ for subgroup difference). (c) Forest plot meta-analysis of the prevalence of olfactory dysfunction only including studies conducted in Europe for the three periods showed $45.2 \%, 65.4 \%$, and $59.0 \%$ pooled subgroup prevalence in the random-effect model, respectively $(P=0.013$ for subgroup difference). (d) Forest plot meta-analysis of the prevalence of gustatory dysfunction of the three periods showed $49.8 \%$, $60.2 \%$, and $49.3 \%$ pooled subgroup prevalence in the random-effect model, respectively $(P=0.538$ for subgroup difference). The diamonds represent pooled prevalence with $95 \%$ confidence interval, and the estimates of individual studies are represented as squares, with $95 \%$ confidence intervals represented as horizontal lines.

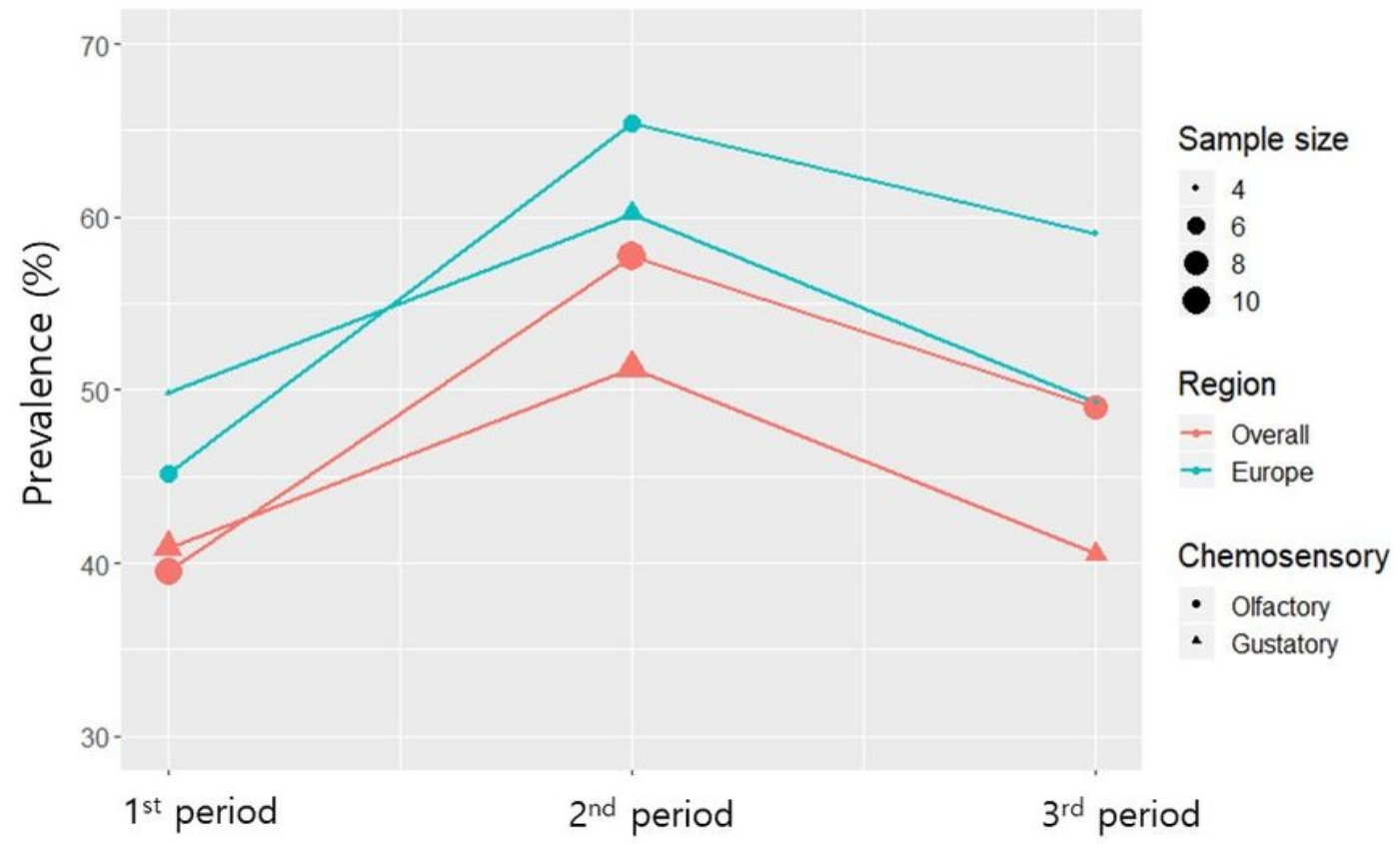

The time of enrollment

\section{Figure 5}

The pooled prevalence of olfactory and gustatory dysfunction was presented chronologically. The overall and European pooled prevalences of olfactory and gustatory dysfunction are shown, discriminated by color. The prevalences of both olfactory and gustatory tended to increase from the $1 \mathrm{st}$ to 2 nd period but decreased from the 2 nd to 3 rd period. 

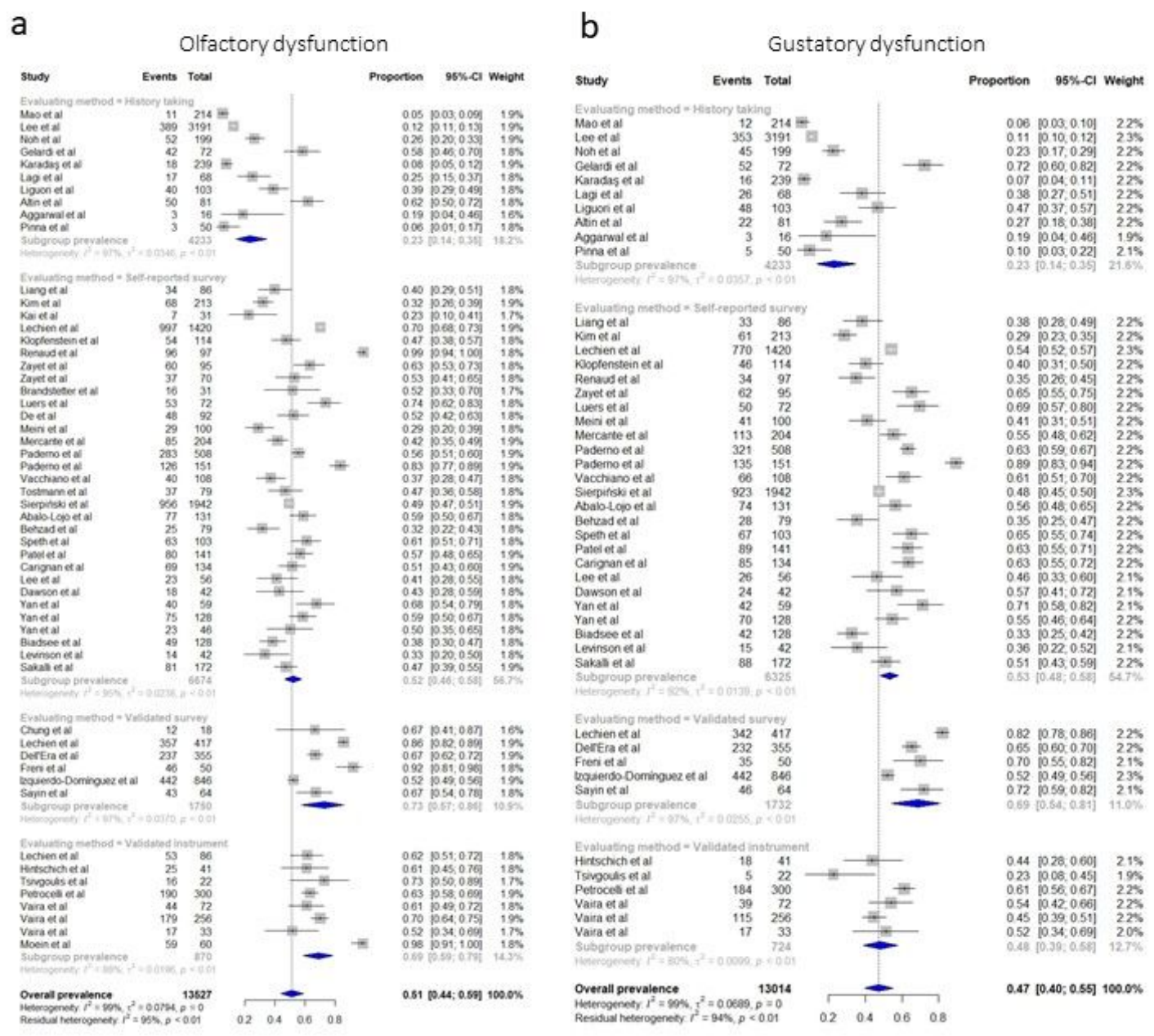

\section{Figure 6}

Subgroup analysis on the evaluation method. The evaluation method was classified into history taking, selfreported survey, validated survey, and validated instrument. (a) Forest plot meta-analysis of the prevalences of olfactory dysfunction of the four evaluation methods showed $23.4 \%, 52.1 \%, 72.9 \%$, and $69.2 \%$ pooled subgroup prevalence in random-effect model, respectively $(P<0.001$ for subgroup difference). (b) Forest plot meta-analysis of the prevalences of gustatory dysfunction of the four evaluation methods showed $23.5 \%$, $53.2 \%, 68.5 \%$, and $48.4 \%$ pooled subgroup prevalence in random-effect model, respectively $(P<0.001$ for subgroup difference). The diamonds represent pooled prevalence with $95 \%$ confidence interval, and the 
estimates of individual studies are represented as squares, with 95\% confidence intervals represented as horizontal lines.

a

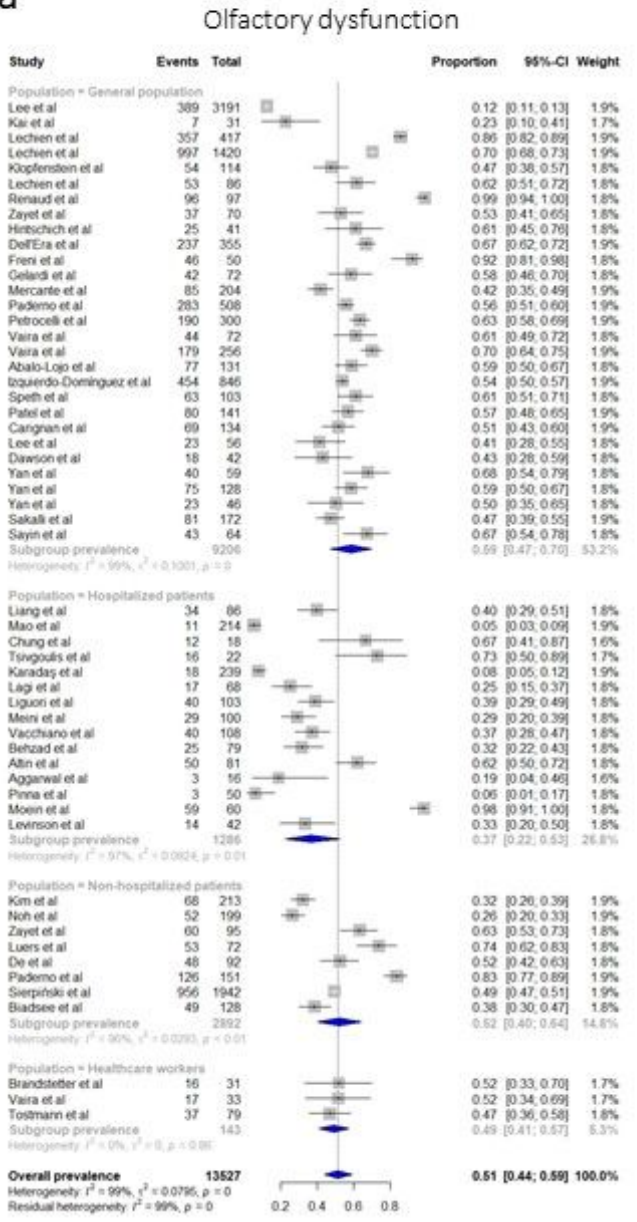

b

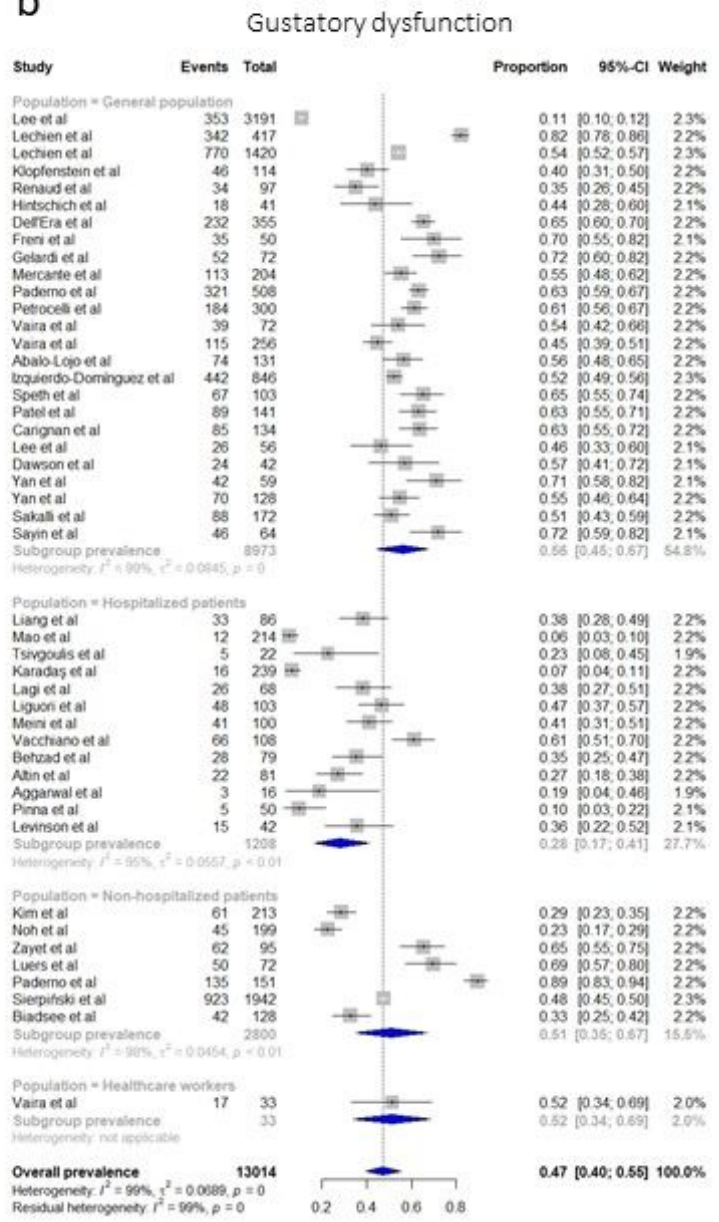

Figure 7

Subgroup analysis on the characteristics of population. The characteristics of population was classified into general population, hospitalized population, non-hospitalized population, and population of healthcare workers. (a) Forest plot meta-analysis of the prevalence of olfactory dysfunction of the four demographics showed $58.7 \%, 36.7 \%, 52.3 \%$, and $48.9 \%$ pooled subgroup prevalence in the random-effect model, respectively ( $P<0.001$ for subgroup difference). (b) Forest plot meta-analysis of the prevalences of gustatory dysfunction 
of the four demographics showed $56.2 \%, 28.3 \%, 51.1 \%$, and $51.5 \%$ pooled subgroup prevalence in randomeffect model, respectively $(P<0.001$ for subgroup difference). The diamonds represent pooled prevalence with $95 \%$ confidence interval, and the estimates of individual studies are represented as squares, with $95 \%$ confidence intervals represented as horizontal lines.

\section{Supplementary Files}

This is a list of supplementary files associated with this preprint. Click to download.

- Supplementarymaterials.docx 